\title{
Waste Handling Practices for the Plutonium Immobilization Plant
}

\author{
T. F. Severynse
}

\section{August 4, 2000}

U.S. Department of Energy

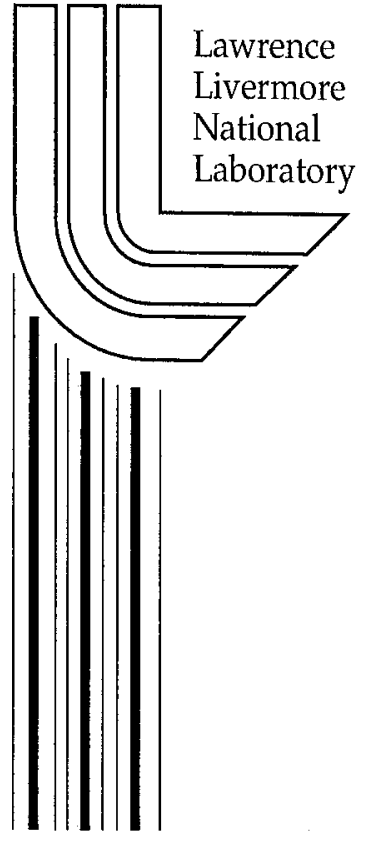




\section{DISCLAIMER}

This document was prepared as an account of work sponsored by an agency of the United States Government. Neither the United States Government nor the University of California nor any of their employees, makes any warranty, express or implied, or assumes any legal liability or responsibility for the accuracy, completeness, or usefulness of any information, apparatus, product, or process disclosed, or represents that its use would not infringe privately owned rights. Reference herein to any specific commercial product, process, or service by trade name, trademark, manufacturer, or otherwise, does not necessarily constitute or imply its endorsement, recommendation, or favoring by the United States Government or the University of California. The views and opinions of authors expressed herein do not necessarily state or reflect those of the United States Government or the University of California, and shall not be used for advertising or product endorsement purposes.

Work performed under the auspices of the U. S. Department of Energy by the University of California Lawrence Livermore National Laboratory under Contract W-7405-Eng-48.

This report has been reproduced directly from the best available copy.

Available to DOE and DOE contractors from the Office of Scientific and Technical Information

P.O. Box 62, Oak Ridge, TN 37831

Prices available from (423) 576-8401 http://apollo.osti.gov/bridge/

Available to the public from the National Technical Information Service

U.S. Department of Commerce 5285 Port Royal Rd., Springfield, VA 22161 http://www.ntis.gov/

OR

Lawrence Livermore National Laboratory Technical Information Department's Digital Library http://www.llnl.gov/tid/Library.html 


\section{WASTE HANDLING PRACTICES \\ FOR \\ THE PLUTONIUM IMMOBILIZATION PLANT}

April, 2000

\section{INTRODUCTION}

Solid waste handling operations refers to all activities associated with the segregation, collection, packaging, assay, storage, and removal of solid radioactive waste from radiological facilities. The Plutonium Immobilization Plant (PIP) is expected to generate the following types of radiological waste, as defined in WSRC Manual 1S, "Waste Acceptance Criteria":

- Low level waste

- Mixed hazardous waste

- TRU waste

- Mixed TRU waste

Historically, waste handling activities have been demanding proportionately larger amounts of labor, time, and space to effectively manage waste in accordance with increasing regulatory requirements. Since the PIP will be designed for an annual throughput of five metric tonnes plutonium, the facility waste handling operations can be expected to have at least twice the impact of such operations at existing facilities.

Waste Handling can impact several areas of facility operations, including criticality safety, radiological exposure, material transport, and equipment maintenance. The accumulation of residual powder in a glovebox, in process scrap, or failed equipment may contain substantial quantities of plutonium, and can present a significant radiological source term to be handled manually. (This condition may initiate waste removal operations in an individual process cabinet.) To reduce personnel exposure to acceptable levels, the waste removal process may require material deinventory of the process equipment, with corresponding impact on both upstream and downstream process operations. Therefore, the safe and efficient removal of waste from process gloveboxes also represents a critical activity with respect to facility throughput.

This report will evaluate current waste handling operations at existing plutonium facilities, and proposes practices and methods to be implemented in PIP based on the current facility layout and equipment arrangement. In addition, some specific issues that are unique to PIP process operations will be discussed, and PIP-specific waste related documents and procedures that are required for hot operations will be identified. 


\section{EXISTING FACILITIES WASTE HANDLING PRACTICES}

A walkdown of 221-F\&H B-Lines solid waste handling activities was performed in March of FY00 to evaluate existing practices and their applicability to new facilities for the Plutonium Disposition programs.

\section{- HB-LINE}

HB-Line generates two types of radioactive solid waste, as defined in WSRC Manual 1S, "Waste Acceptance Criteria": low-level waste, and unclassified TRU waste. No classified waste is generated in the facility. Cabinet waste generated from normal process and maintenance activities is taped together and passed through the process line to the end of the cabinet. The waste is then removed via an 18" bagport, and the bag is sealed with tape and surveyed for contamination. The sealed waste bag is placed in a plastic-lined five gallon steel pail. When the pail is full, the liner is taped closed, and the lid is placed on the pail. The lid is then taped and a TID seal is placed on the lid to prevent unauthorized removal of the unmonitored waste. The pail is transported to temporary storage, pending assay measurement. Movement and storage of unmeasured Containers is strictly controlled: the facility is divided procedurally into transport zones, and only one container may be moved within a zone at any time. Materials are not permitted to cross transport zone boundaries unless specifically authorized by procedures. Unmonitored pails are stored in open racks that provide geometrically favorable spacing requirements.

The waste pails are monitored using a segmented gamma scanner (SGS), which provides a measurement of both ${ }^{238} \mathrm{Pu}$ and ${ }^{239} \mathrm{Pu}$ in each container. Present operations require successive 30-minute cycles to measure each isotope independently; future software modifications will allow simultaneous measurement of both isotopes in one cycle. Monitored waste pails are moved to a repackaging room for waste loading into TRU drums.

Waste packaging is performed by movement of the five-gallon pails into a large containment hut. The bagged waste is removed from the pail, surveyed for contamination, and placed into a 55-gallon TRU drum. A running inventory of plutonium is maintained for each drum, based on the contents of each individual pail. Used pails are surveyed and clean pails are removed from the hut for reuse.

When the 55-gallon drums are full, they are closed with a drum lid, and TID sealed prior to movement to the 221-H Southwest loading dock for transfer to Solid Waste Management.

Low level waste, consisting of containment hut waste, discardable protective clothing, tools, and other materials from radiological areas, is collected in receptacles at designated areas. Waste collection may be segregated based on physical characteristics and curie 
determinations. The bags of waste from the receptacles are collected periodically and surveyed (dose rate or smear) to verify that the curie content is consistent with the characterization plan estimates for that stream. The bags are sealed when surveying is complete.

The sealed bags are labeled, weighed, and identified with a unique number for recording in the facility waste $\log$ that is maintained for each B-25 container. Full B-25 containers are sealed before transfer to the E-Area vaults.

\section{- FB-LINE}

FB-Line generates low-level, TRU, and some mixed TRU waste from process operations. Waste removed from process glovebox lines is similar to that for HB-Line, however due to the isotopic content of FB-Line plutonium materials (weapons-grade - high fissile content), the administrative controls are more rigorous. Material is removed from a process cabinet via a bagport, and placed in a five-gallon waste pail, which is TID-sealed and moved (with Protective Force escort) for fissile monitoring at the Confirmatory Measurement Counter (CMC). The CMC is a "go/no-go" device that provides a rough measurement of ${ }^{239} \mathrm{Pu}$ content in the pail. Surveyed pails are transferred based on fissile content: monitored pail storage ( $<60$ grams), nuclear safety restraint storage (60-100 grams), or segregated for possible material recovery (> 100 grams).

When ready for disposal, the individual waste pails are assayed using a segmented gamma scanner (SGS) similar to the HB-Line system, or portable gamma monitor. The waste is then transferred from the pail to a TRU drum in the repackaging hut. When full, the drum is fitted with a TID seal, and monitored using a neutron coincidence counter prior to removal from the facility. This final drum survey is used to satisfy security requirements for movement outside the Material Access Area boundary.

Oversized TRU waste expected to contain appreciable amounts of fissile material are packaged directly into drum liners or wooden burial boxes. These packages are TIDsealed, and monitored with a portable gamma monitor prior to transfer to interim storage.

\section{PLUTONIUM IMMOBILIZATION FACII ITY OPERATIONS}

- Glovebox Waste (TRU)

The Plutonium Immobilization facility consists of four primary process areas: material receipt and storage, Plutonium conversion, first stage immobilization, and canister loading. The majority of radioactive waste will be generated in the plutonium conversion and first stage immobilization areas. All waste removed from these process cabinets is assumed to be TRU. Material movement between gloveboxes is performed remotely via an overhead conveyor system. Due to radiation exposure concerns, most process operations are automated, with intermittent personnel access for surveillance, maintenance, and waste handling operations. 
The facility design for waste handling includes a 50' $\mathrm{L}$ x 6' $\mathrm{H}$ x $4^{\prime} \mathrm{W}$ shielded glovebox, located in a $30^{\prime} \times 50^{\prime}$ room. Located adjacent to this room are storage areas for waste drums, and a drum assay device. The glovebox functions as a repackaging hut for process cabinet waste. Waste from process cabinets will be collected in waste pails, and monitored at-line by an external "go/no-go" device to establish a maximum limit for fissile material content. The monitored pails are transferred via the overhead conveyor to the Waste Handling Glovebox for:

$$
\begin{aligned}
& \text { - assay } \\
& \text { - sampling/waste characterization } \\
& \text { - material recovery } \\
& \text { - repackaging to drums }
\end{aligned}
$$

Use of the "go/no-go" pail monitor prior to removal of the waste from the process glovebox allows more efficient, unrestricted use of the conveyor system, and also allows accumulation of pails in the Waste Handling glovebox. Pails that have been emptied of waste will be recycled or reuse.

At the Waste Handling glovebox, incoming pails are placed in a designated storage location until pail assay in a segmented gamma scanner has been completed. The assayed pails are then moved to monitored pail storage, awaiting repackaging into drums.

Waste is removed from the pails and transferred to an adjacent hood and loaded into drums until space, weight, or curie limitations have been reached. When filled the drums are closed, TID-sealed, surveyed for contamination, and moved to storage awaiting final assay by a neutron multiplicity counter or neutron coincidence counter.

A material flow diagram for TRU waste is shown in Figure 1.

\section{- Job Control \& Other Waste (Low Level Waste)}

Waste of this type includes containment huts, decontamination waste, tools, paper, plastic, and discarded personnel protective clothing that has incidental contact with contamination, but has not been grossly contaminated to TRU levels. Low level waste must be segregated and carefully monitored to ensure that it meets disposal limits of $<100 \mathrm{nCi}$ per gram of waste matrix. Suspect TRU waste that is below minimum detection limits may also meet LLW requirements.

Low level waste is accumulated in bags located in receptacles throughout the facility. When full, the bags are inspected, sealed, and monitored (dose rate or smear), to determine a curie inventory. The bags of waste are then weighed prior to disposal in a B25 box. Administrative control of partially-filled B-25s requires that they be locked when not in use.

A material flow diagram for low-level waste is shown in Figure 2. 
The PIP facility Waste Handling room equipment for low level waste handling will include a weigh scale and waste monitor (such as the Canberra $\mathrm{Q}^{2}$ ) that can discriminate between low level and TRU waste for low density material.

\section{DOCUMENTS TO BE GENERATFD}

The following documents are required for the PIP to generate solid waste for acceptance at a site disposal/treatment facility:

- Waste Certification Plan

A document that outlines the facility program, including procedures and methodologies, for waste characterization and certification

- Waste Characterization Plan

A document that describes the program for determination of the physical, chemical, and radiological properties of a waste in order to comply with applicable storage, handling, transportation and disposal requirements.

- Radioisotope Characterization Plan

A strategy that describes the radionuclide distribution and develops a method for quantifying the radioisotopic content of low level waste packages.

- Radioisotope Sampling Plan

A document that describes statistical sampling methods used to validate radioisotope distribution.

\section{- Chemical Characterization Plan}

A document that identifies and describes the presence, use, and control of hazardous materials used in the facility that may enter the waste stream.

- Software Quality Assurance Plan for Instrumentation

A document that describes the operation and maintenance of monitoring instrumentation, in accordance with manual 1Q, QAP 20-1.

- Waste Minimization Plan

A document that describes the facility program for reduction of all waste streams to mitigate the environmental and cost impacts. 


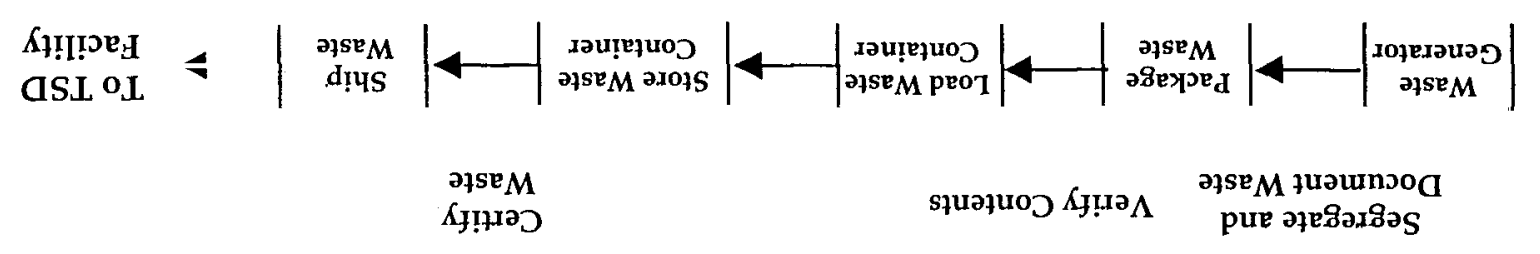

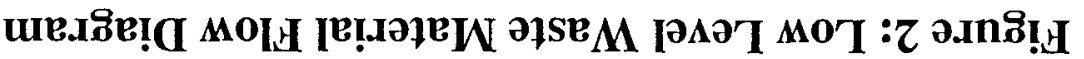

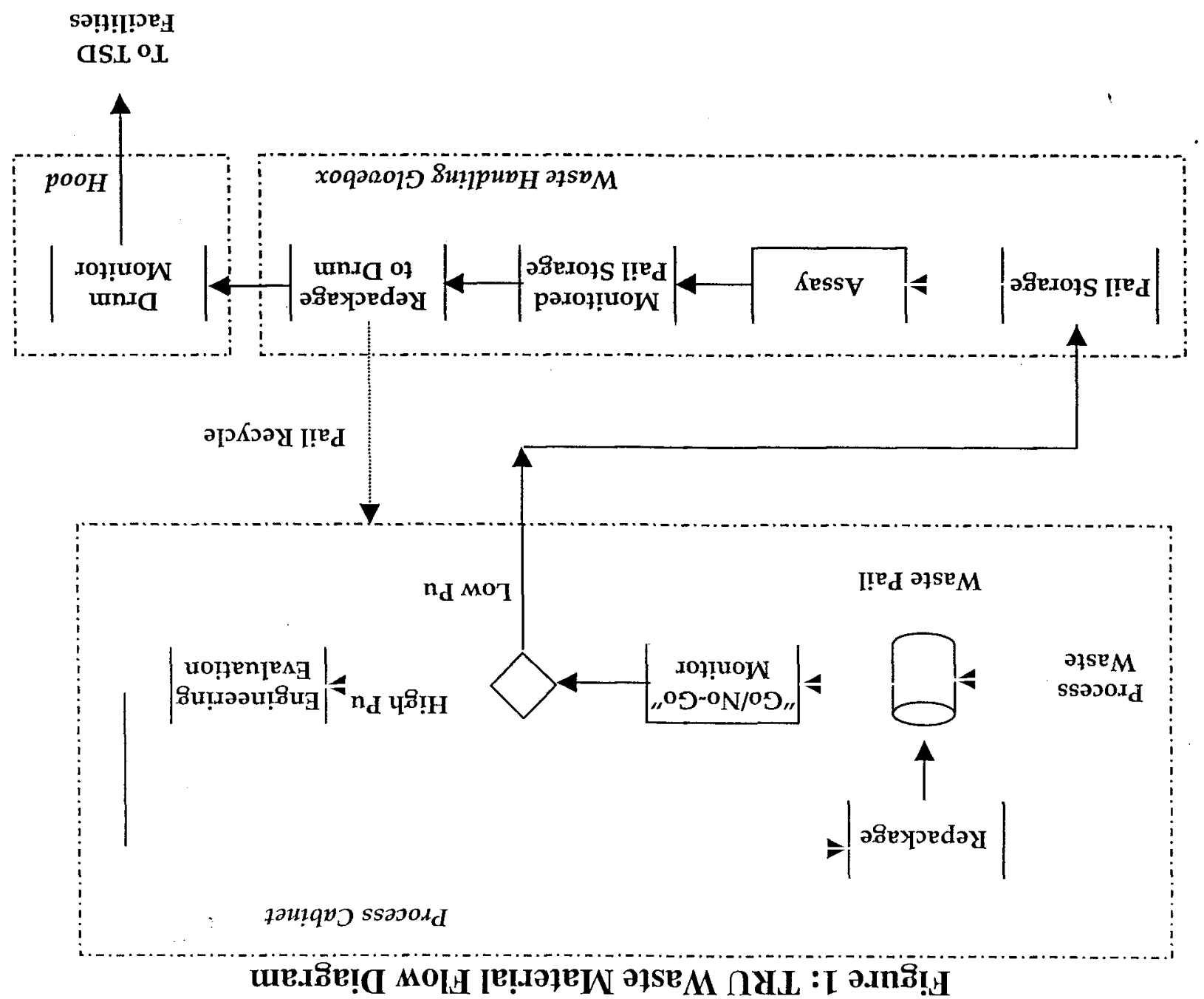

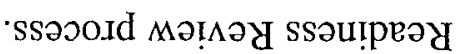

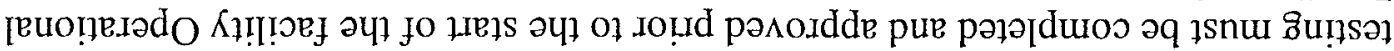

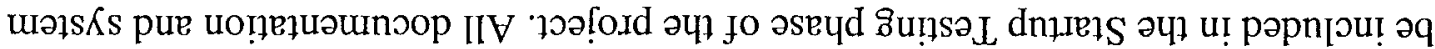
II!M 'quәud!nb

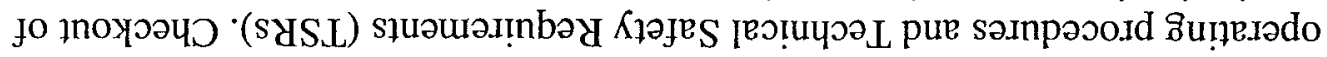

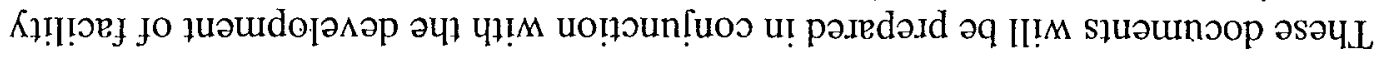




\section{ISSUES}

Waste handling activities will be performed under facility-specific procedures derived from $1 \mathrm{~S}$ manual requirements. Although the majority of waste generated from PIP can be handled under existing procedures, administrative plans must be developed to ensure that prohibited items and incompatible wastes are excluded from facility waste streams. Due to the nature of the processes involved, PIP waste streams requiring further analysis include:

- Solidified aqueous waste forms

Aqueous waste streams will be generated from the halide washing process, and also from plutonium purification using an anion exchange process. The baseline flowsheet proposes to solidify these aqueous streams by mixing with grout or cement to produce a stabilized monolith. The composition and quality control of the final form must be established and demonstrated to be acceptable for disposal as solid waste.

- Anion resin

Recovery and purification of plutonium from aqueous waste streams will be performed using an anion exchange column. Historically, anion resins from plutonium processes have been disposed by aqueous processing, requiring digestion and neutralization of the resin prior to transfer to site high level waste tanks. In PIP, the resin will be stabilized by displacing residual nitrate ions with sodium sulfate, and drying the resin for packaging and disposal as solid waste. The raffinate from the sulfate wash will also require conversion to grout, as described above.

\section{- Plutonium Nitride}

In the HYDOX process, metallic plutonium is charged to an open frame basket for hydriding. When the reaction is complete, the plutonium hydride falls from the basket into a crucible, where the hydrogen is displaced with nitrogen to form plutonium nitride. This vessel is then transferred to a separate compartment for oxidation of the nitride to plutonium oxide. Any unreacted metal (stainless steel hulls, alloy metal, etc.) remaining in the charging basket will be treated as waste. This material may contain residual amounts of unreacted plutonium in the form of hydrides or nitrides, and may require an intermediate step to ensure that the plutonium is in an acceptable form (metal or oxide) and has been properly characterized for disposal as solid waste.

In addition to specific stability and compatibility issues, it must be determined if these processing steps require regulatory permitting of the facility for treatment of waste. 